\title{
Effects of Lignin on Root Activity and Soil Nutrients of Malus hupehensis. var. pingyiensis under the Use of Organic Fertilizer
}

\author{
Tingwen Lv ${ }^{1,2}$, Hongqiang Yang 3 , Ruixue Zhang ${ }^{3}$, Weiguo Fan ${ }^{3}$, Ying $\mathrm{Xu}^{3}$, Hui Cao ${ }^{3}$, \\ Liufang Ning ${ }^{3}$, Chunran Zhou ${ }^{3}$, Li Wang1,2* \\ ${ }^{1}$ Forestry College of Shandong Agricultural University, Taian, China \\ ${ }^{2}$ Shandong Provincial University Key Laboratory of Silviculture, Taian, China \\ ${ }^{3}$ College of Horticulture Science and Engineering, Shandong Agricultural University, Taian, China \\ Email: *liwang6868@aliyun.com
}

How to cite this paper: Lv, T.W., Yang, H.Q., Zhang, R.X., Fan, W.G., Xu, Y., Cao, H., Ning, L.F., Zhou, C.R. and Wang, L. (2017) Effects of Lignin on Root Activity and Soil Nutrients of Malus hupehensis. var. pingyiensis under the Use of Organic Fertilizer. Agricultural Sciences, 8, 341-347. https://doi.org/10.4236/as.2017.85025

Received: March 8, 2017

Accepted: May 15, 2017

Published: May 22, 2017

Copyright $\odot 2017$ by authors and Scientific Research Publishing Inc. This work is licensed under the Creative Commons Attribution International License (CC BY 4.0).

http://creativecommons.org/licenses/by/4.0/

c) (i) Open Access

\begin{abstract}
One-year Malus hupehensis. var. pingyiensis seedlings potted in soil mixed with $10 \%$ or $40 \%$ organic fertilizer were treated with two concentrations of lignin (1.5 and $\left.2.5 \mathrm{~g} \cdot \mathrm{kg}^{-1}\right)$, and detected the effects of lignin on root activity and soil nutrients in rhizosphere soil of Malus hupehensis. var. pingyiensis. (1) Lignin improved root activity of Malus hupehensis. var. pingyiensis, increased soil available nitrogen contents and soil organic matter contents. (2) Under $10 \%$ organic fertilizer, lignin improved soil available $\mathrm{P}$ and $\mathrm{K}$ contents. The root activity in Malus hupehensis. var. pingyiensis was the largest in 2.5 $\mathrm{g} \cdot \mathrm{kg}^{-1}$ lignin treatment. (3) Under $40 \%$ organic fertilizer, compared with the CK2 (the treatment of soil with organic fertilizer content $40 \%$ ), lignin decreased the content of rhizosphere soil available K. $1.5 \mathrm{~g} \cdot \mathrm{kg}^{-1}$ lignin treatment had obviously increased the content of soil available P. The root activity was the largest in $2.5 \mathrm{~g} \cdot \mathrm{kg}^{-1}$ lignin treatment, while the content of rhizosphere soil available $\mathrm{K}$ lowered $8.5 \%$ compared with that of CK2 in the same treatment. Lignin changed the soil nutrients, $2.5 \mathrm{~g} \cdot \mathrm{kg}^{-1}$ lignin significantly improved root activity of Malus hupehensis. var. pingyiensis. The results provided a theoretical basis for the regulation of root activity and soil nutrients in Malus hupehensis. var. pingyiensis.
\end{abstract}

\section{Keywords}

Malus hupehensis. var. pingyiensis, Lignin, Organic fertilizer, Nutrients

\section{Introduction}

Lignin is the only resource that provides renewable aromatic compounds. A 
large amount of alkaline lignin from paper-making waste liquor, its utilization rate is very low, nowadays, less than $10 \%$ of the lignin can be converted into a valuable product [1]. Lignin improved soil aggregate structure, reduced the soil adsorption capacity to fix the soil nutrients, and raised the fertilizer efficiency of the nitrogen and phosphorus [2] [3] [4]. Lignin regulated non-organic nitrogen release, benefited the soil $\mathrm{N}$ supplying and the $\mathrm{N}$ and $\mathrm{P}$ uptake, increased the growth and quality of plant and reduced the soil pollution [5] [6]. Lignin has also the absorption capacity of heavy metal ion such as $\mathrm{Cu}^{2+}, \mathrm{Pb}^{2+}, \mathrm{Hg}^{2+}, \mathrm{Cd}^{2+}[7]$ [8] and the high antioxidant capacity [9].

Therefore, how to effectively use lignin is an important hot problem. Because of single nutritional components of lignin, it is unstable to be single used or applied in poor soil. Malus hupehensis. var. pingyiensis as afforestation tree species is a type of Malus hupehensis and also an excellent apple stock. One-year Malus hupehensis. var. pingyiensis seedlings potted in soil mixed with organic fertilizer were treated with different concentrations of lignin, detected the effects of lignin on root activity and soil nutrients in rhizosphere soil were analyzed. The purpose of this research is to provide a theoretical basis for the better use of lignin, regulation root soil nutrients and the rational cultivation of Malus hupehensis. var. pingyiensis in China and other countries.

\section{Material and Methods}

\subsection{Study Sites}

This study was conducted in march-september in 2015 in Science and technology innovation park in the south campus of Shandong agricultural university, Taian, China. The tested plants are one-year Malus hupehensis. var. pingyiensis seedlings potted in soil. The pot used in this test has $36 \mathrm{~cm}$ mouth diameter, 27 $\mathrm{cm}$ height, the soil weight of each pot is $10.2 \mathrm{~kg}$. The soil has the following properties: soil available nitrogen $54.9 \mathrm{mg} \cdot \mathrm{kg}^{-1}$, available phosphorus $27.3 \mathrm{mg} \cdot \mathrm{kg}^{-1}$, available potassium $33.9 \mathrm{mg} \cdot \mathrm{kg}^{-1}$, organic matter $12.4 \mathrm{~g} \cdot \mathrm{kg}^{-1}, \mathrm{pH} 7.3$. The organic fertilizer has the following nutrients: soil available nitrogen $255.5 \mathrm{mg} \cdot \mathrm{kg}^{-1}$, available phosphorus $50.7 \mathrm{mg} \cdot \mathrm{kg}^{-1}$, available potassium $65.9 \mathrm{mg} \cdot \mathrm{kg}^{-1}$, organic matter $164.3 \mathrm{~g} \cdot \mathrm{kg}^{-1}$. The tested lignin is alkaline lignin manufactured from the company of Shandong province.

\subsection{Experiment Treatment}

Firstly, $0,1.5,2.5 \mathrm{~g} \cdot \mathrm{kg}^{-1}$ lignin was added in the soil with organic fertilizer content $10 \%$ and $40 \%$, respectively (Table 1 ), secondly, the above materials as experimental soil fully mixed with were put into the pots. The one-year Malus hupehensis. var. pingyiensis seedlings were planted in these pots, each treatment was designed in triplicate.

\subsection{Determination}

The roots and soil were picked up, and the sorted out roots were used to measure. The soil was sampled in September in 2015. After the surface soil was re- 
Table 1. Experimental treatments.

\begin{tabular}{cc}
\hline Organic fertilizer applied (quanlity fraction \%) & Lignin applied $\left(\mathrm{g} \cdot \mathrm{kg}^{-1}\right)$ \\
\hline & $0(\mathrm{CK} 1)$ \\
10 & 1.5 \\
& 2.5 \\
40 & $0(\mathrm{CK} 2)$ \\
& 1.5 \\
& 2.5 \\
\hline
\end{tabular}

moved, root activity, the seized soil through natural air dry was applied to determine soil nutrient content and soil enzyme activities.

Root activity was measured according to the triphenyltetrazolium chloride method [10]. Soil organic matter was measured according to the method [11]. The content on soil alkaline $\mathrm{N}$, soil available $\mathrm{P}$, soil available $\mathrm{K}$ was measured based on the method [12].

\subsection{Data Analysis}

The data in the article were analyzed through Excel statistical software and SPSS 17.0 statistical software package.

\section{Results}

\subsection{Root Activity}

The root activity of Malus hupehensis. var. pingyiensis became larger with the increase of lignin concentration, regardless of $10 \%$ or $40 \%$ organic fertilizer content. The root activity of the species in $2.5 \mathrm{~g} \cdot \mathrm{kg}^{-1}$ lignin treatment became bigger by $89.5 \%$ compared with that of the CK (Figure $1(\mathrm{a})$ ). Under the condition of $40 \%$ organic fertilizer, the root activity of the species in $1.5 \mathrm{~g} \cdot \mathrm{kg}^{-1}$ lignin treatment was no significant difference compared with that in the $2.5 \mathrm{~g} \cdot \mathrm{kg}^{-1}$ lignin treatment, and that of the species in $2.5 \mathrm{~g} \cdot \mathrm{kg}^{-1}$ lignin treatment was higher $55.0 \%$ than that in the CK2 (Figure 1(b)).

\subsection{Rhizosphere Soil Nutrients}

Soil nutrients differently varied in those lignin treatments (Figure 2). Soil available $\mathrm{N}$ and organic matter became gradually larger with the increase of lignin used. Among those treatments, that of soil available $\mathrm{N}$ and organic matter were largest in $2.5 \mathrm{~g} \cdot \mathrm{kg}^{-1}$ lignin treatment, they raised by $27.3,68.4 \%$ compared with that of CK1 under $10 \%$ organic fertilizer, respectively, and increased by $42.8 \%$, $15.2 \%$ compared with that of CK2 under $40 \%$ organic fertilizer, respectively.

Under $10 \%$ organic fertilizer, the content of soil available $\mathrm{P}$ and organic matter of $1.5 \mathrm{~g} \cdot \mathrm{kg}^{-1}$ lignin treatment became larger by $5.6 \%, 49.1 \%$, respectively, soil alkaline $\mathrm{N}$ of $1.5 \mathrm{~g} \cdot \mathrm{kg}^{-1}$ lignin treatment had an decrease compared with that of $\mathrm{CK}$. The $1.5 \mathrm{~g} \cdot \mathrm{kg}^{-1}$ lignin treatment elevated the content soil available $\mathrm{K}$ by $16.0 \%$ compared with that of CK1. 


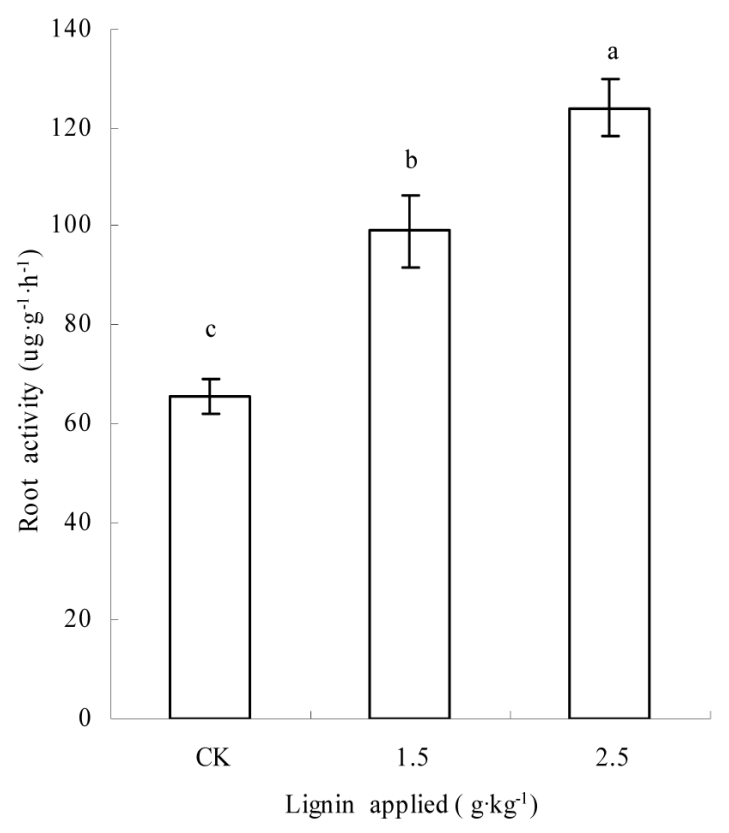

(a)

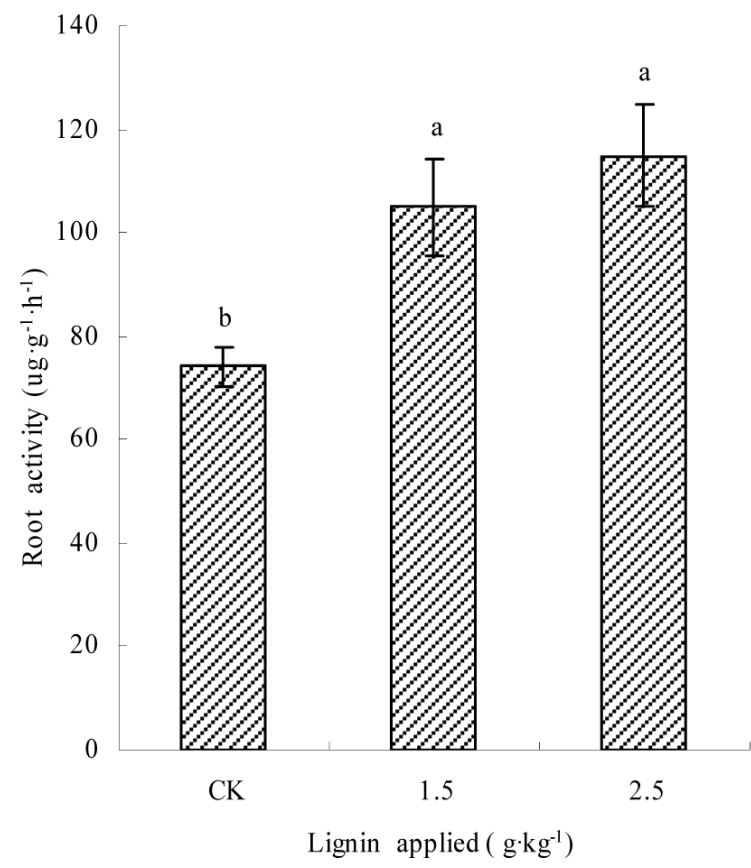

(b)

Figure 1. Changes of root activity of Malus hupehensis var. pinyiensis. Note: Figure 1A represents $10 \%$ organic fertilizer condition; Figure 1B represents $40 \%$ organic fertilizer condition.

Under $40 \%$ organic fertilizer, the two concentrations of lignin treatment elevated the content of soil available $\mathrm{P}$, but had no significant difference compared with that of CK2. Different concentrations of lignin treatments decreased the content of rhizosphere soil available potassium, and that of rhizosphere soil available $\mathrm{K}$ in $2.5 \mathrm{~g} \cdot \mathrm{kg}^{-1}$ lignin treatment lowered $8.5 \%$ compared with that of CK2 (Figure 2). 

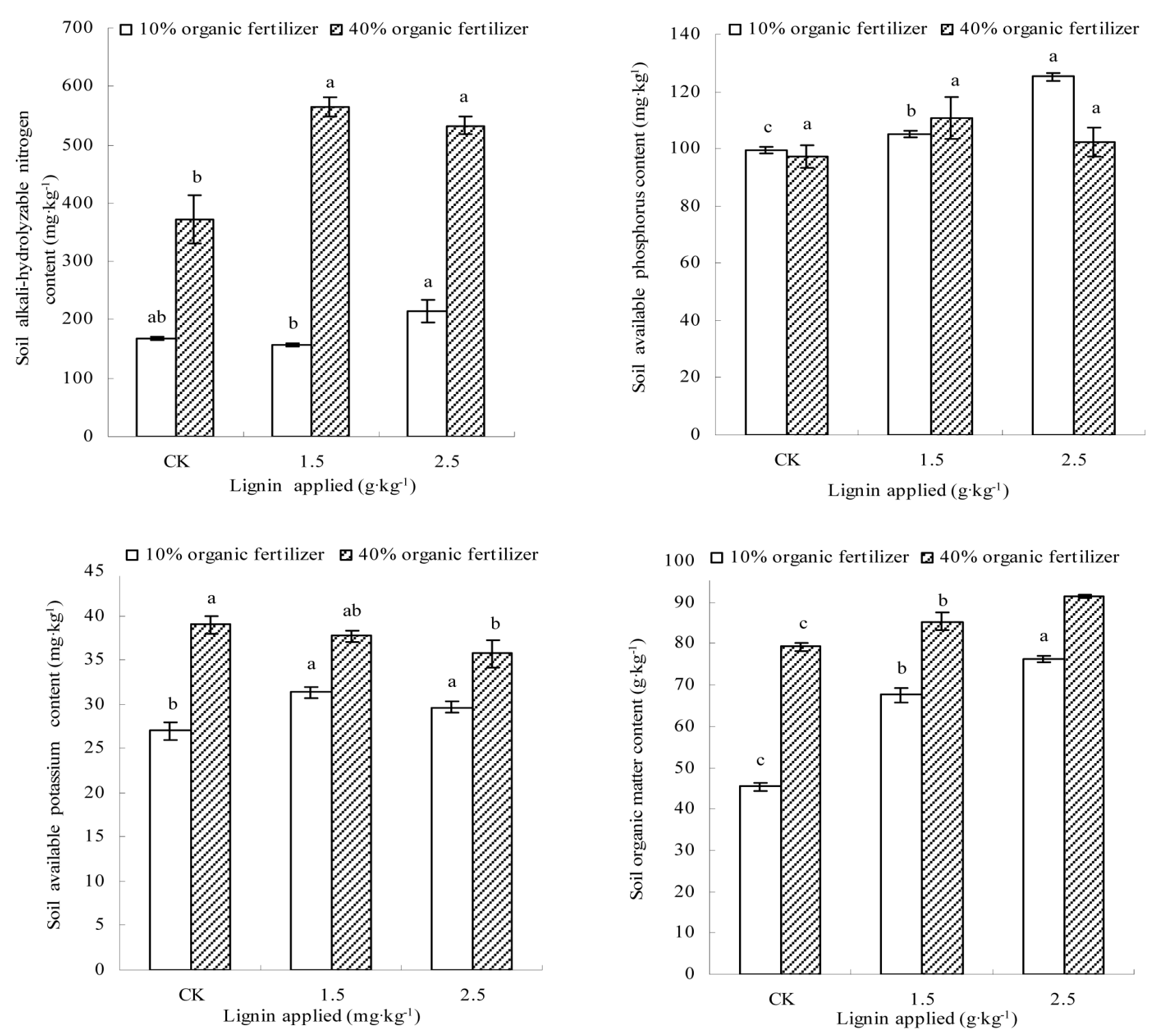

Figure 2. Changes of soil nutrient contents in rhizosphere soil of Malus hupehensis var. pinyiensis.

\section{Discussion}

\subsection{Soil Nutrients}

Soil fertility mainly depends on the amount of soil nutrients. The content of soil nutrients significantly raised after soil was applied with organic compound fertilizer. Soil organic matter correlated positively with soil organic carbon (SOC). Straw, lignin and biochar obviously increased the content of SOC [13]. Lignin could reduced the Fixation of soil P by metal ions, insoluble P could be rapidly resolved, which promoted the plant growth [14]. After used the lignin slow-release fertilizer in soil, the content of effective $\mathrm{K}$ raised, the $\mathrm{K}$ requirement for plant had an increase with its growth, which resulted in the steady declination of soil available $\mathrm{K}$ content [15].

Under the application of organic fertilizer, lignin increased the content of alkaline $\mathrm{N}$ and organic matter. In the condition of $10 \%$ organic fertilizer, the 
amount of soil available $\mathrm{P}$ and $\mathrm{K}$ became larger, the result was coincided with the informed report [16], the reason lied in that lignin enlarged the effectivity of soil $\mathrm{P}$ and $\mathrm{N}$, promoted the accumulation of soil available $\mathrm{K}$ [15]. However, the content of soil alkaline $\mathrm{N}$ in $1.5 \mathrm{~g} \cdot \mathrm{kg}^{-1}$ lignin treatment had an decrease, the reason might be that the thriving trees in $1.5 \mathrm{~g} \cdot \mathrm{kg}^{-1}$ lignin treatment had assimilated much more soil alkaline $\mathrm{N}$. In the condition of $40 \%$ organic fertilizer, the amount of soil available $\mathrm{K}$ became much smaller with the concentration of lignin among the treatments, which might be that lignin promoted the Malus hupehensis. var. pingyiensis growth, this tree absorbed more soil $\mathrm{K}$, the study was similar to the reported research [16]. The amount of soil available $\mathrm{P}$ was lower in the $2.5 \mathrm{~g} \cdot \mathrm{kg}^{-1}$ lignin treatment than that in the $1.5 \mathrm{~g} \cdot \mathrm{kg}^{-1}$ lignin treatment, it might be that the trees of $2.5 \mathrm{~g} \cdot \mathrm{kg}^{-1}$ lignin treatment were higher among the treatments and they consumed more soil $\mathrm{P}$.

\subsection{Root Activity}

Root activity is an important index reflecting the ability of root to absorb soil nutrients and water and directly affecting the growth of plant. Root activity was affected by organic matter, fertilizer, plant cultivars, microbial number and other environmental factors [16] [17]. The application of lignin increased root activity of Malus hupehensis. var. pingyiensis, the reason may be that lignin improved the content of soil nutrients (Figure 2), promoted the absorption of root to soil nutrients.

\section{Conclusion}

Lignin improved its root activity, increased soil available nitrogen and soil organic matter contents. Under $10 \%$ organic fertilizer, lignin improved soil available $\mathrm{P}$ and $\mathrm{K}$ contents. Under $40 \%$ organic fertilizer, lignin decreased the content of soil available $\mathrm{K}$, the root activity was the largest in $2.5 \mathrm{~g} \cdot \mathrm{kg}^{-1}$ lignin treatment, while the content of soil available $\mathrm{K}$ lowered. In all, lignin changed the soil nutrients, $2.5 \mathrm{~g} \cdot \mathrm{kg}^{-1}$ lignin significantly improved root activity of Malus hupehensis. var. pingyiensis.

\section{Funding}

This work was supported by "five-twelfth" Nation Science and Technology Support Program of China (Grant No. 2014BAD16B02).

\section{References}

[1] Ge, Y.L., Zhao, X.H., Zu, Y.G., Li, W.G., Li, Y. and Sun, X.L. (2013) Analysis of Primary Physicochemical Properties of Three Kinds of Lignin. Bulletin of Botanical Research, 33, 766-769.

[2] Camberato, J.J., Gagnon, B., Angers, D.A., Chantigny, M.H. and Pan W.L. (2006) Pulp and Paper Mill By-Products as Soil Amendments and Plant Nutrient Sources. Canadian Journal of Soil Science, 86, 641-653. https://doi.org/10.4141/S05-120

[3] Li, X.J., Wang, D.H., Zhang, Y.S., Huang, X.H. and Liao, Z.W. (2006) Effects of Lig- 
nin on the Nitrogen Migration, Transformation and Accumulation of Compound Fertilizer Coated with Lignin in Multimedia Environment. Journal of Agro-Environment Science, 25, 458-463.

[4] Ju, M., Weng, C.J. and Liu, J.H. (2011) The Application of Lignin in Agriculture. Modern Agriculture, 1, 27-28.

[5] Chen, Q., Mu, H.Z., Huang, Y.C. and Yang, W.B. (2004) Effects of Application of Lignin on the Growth and Yield of Spring Maize. Chinese Journal of Eco-Agriculture, 12, 92-94.

[6] Zhang, J., Wang, H., Li, S.T. and Liu, R.L. (2010) Effects of Applied Lignin on Urea Transformation and Release in Soil. Soil and Fertilizer Sciences in China, 5, 16-20.

[7] Liu, X.L., Zhu, H.X., Qin, C.R., Zhou, J.H., Zhao, J.R. and Wang, S.F. (2013) Adsorption of Heavy Metal Ion from Aqueous Single Metal Solution by Aminated Epoxy-Lignin. BioResources, 8, 2257-2269.

https://doi.org/10.15376/biores.8.2.2257-2269

[8] Chen, H.S., Cai, A.H., Zhao, Z.G., Meng, Y.H., Qin, X.X. and Zhou, Y.H. (2014) Absorption Properties of Bagasse Lignin on Heavy Metal Ion in Solution. Journal of Guilin University of Technology, 34, 301-305.

[9] Vinardell, M.P., Ugartondo, V. and Mitjans, M. (2008) Application of Lignins from Different Sources as Antioxidant. Detergent \& Cosmetics, 31, 28-30.

[10] Zhao, S.J., Shi, G.A. and Dong, X.C. (2002) Plant Physiology Experiment Instruction. Chinese Agricultural Science Press, Beijing, 47-48.

[11] Qiu, L.J., Huang, G.L., Shuai, Q. and Su, Y. (2015) Reconstruction of the Conversion Relationship between Organic Matter and Total Organic Carbon in Calcination Method and Its Application in Shale Analysis. Rock and Mineral Analysis, 34, 218-223.

[12] Yang, J.H., Wang, C.L. and Dai, X.L. (2008) Soil Chemical Analysis and Environmental Monitoring. China Land Press, Beijing, 26-75.

[13] Zhang, J., Huang, J.S., Liu, J. and Liu, R.L. (2015) Carbon Dioxide Emissions and Organic Carbon Contents of Fluvo-Aquic Soil as Influenced by Straw and Lignin and Their Biochars. Journal of Agro-Environment Science, 34, 401-408.

[14] Huang, Y.Z., Feng, Z.W. and Zhang, F.Z. (2001) Effect of Lignin on N, P Transformation in Soil and Corn Yield. Chinese Journal of Eco-Agriculture, 9, 75-77.

[15] Zhang, A.F. (2014) Effect of Different Organic-Inorganic Compound Fertilizers on Soil Nutrients and Maize Growth. Master Thesis, Shan Dong Agriculture University, China, 20-21.

[16] Wang, D.H., Peng, J.J., Lin, H.D. and Liao, Z.W. (2003) Effect of Lignosulfonates on Controlling of Urea Nitrogen Transformation and Nitrate Accumulation in Vegetable. Environmental Science, 24, 141-145.

[17] Li, M.J., Yang, L.J., Zhou, C.J., Guo, X.O. and Zhang, Y.M. (2015) Effects of Different Material Combinations on Tomato Root Vigor and Soil Microbiological Characteristics in Greenhouse. Chinese Journal of Soil Science, 46, 883-888. 
Submit or recommend next manuscript to SCIRP and we will provide best service for you:

Accepting pre-submission inquiries through Email, Facebook, LinkedIn, Twitter, etc. A wide selection of journals (inclusive of 9 subjects, more than 200 journals)

Providing 24-hour high-quality service

User-friendly online submission system

Fair and swift peer-review system

Efficient typesetting and proofreading procedure

Display of the result of downloads and visits, as well as the number of cited articles Maximum dissemination of your research work

Submit your manuscript at: http://papersubmission.scirp.org/

Or contact as@scirp.org 